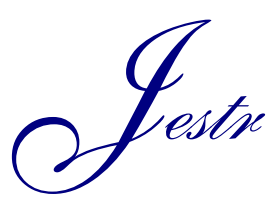

\title{
An Overview of Electrically-enhanced Membrane Bioreactor (EMBR) for Fouling Suppression
}

\author{
K.C. Ho, Y.H. Teow ${ }^{*}$ W.L. Ang, A.W. Mohammad \\ Department of Chemical and Process Engineering, Faculty of Engineering and Built Environment, Universiti Kebangsaan Malaysia, 43600 \\ Bangi, Selangor Darul Ehsan, Malaysia. \\ Centre for Sustainable Process Technology (CESPRO), Faculty of Engineering and Built Environment, Universiti Kebangsaan Malaysia, \\ 43600 Bangi, Selangor Darul Ehsan, Malaysia.
}

Received 19 December 2016; Accepted 15 July 2017

\begin{abstract}
Membrane fouling is the major challenges that hinders the widespread application of membrane bioreactor (MBR). Recently, application of electricity in electrically-enhanced MBR (EMBR) to suppress membrane fouling has gained much attention among research communities. This paper presents an overview of developments on EMBR for fouling suppression in wastewater treatment. The flow of electricity has stimulated several electrokinetic processes including electrophoresis/electrochemical process, and electrocoagulation which are the major fouling suppression mechanisms employed in EMBR. In electrophoresis, the membrane fouling is suppressed by the increased electrorepulsive force between negatively-charged foulants and cathode membrane under the influence of an electric field. Besides, electric field also induces simultaneous electrochemical oxidation and reduction which generate chemicals to degrade pollutant in wastewater. On top of that, use of active anode is reminiscent of electrocoagulation which produces cation coagulants in EMBR that capable to neutralize charge of the foulants and promotes flocs formation. This increases flocs size and sedimentation rate thereafter reduces adhesion of foulants on the membrane surface. Lastly, bioelectricity generation of microbial fuel cell (MFC) integrated with MBR to attain self-sustained EMBR has been studied. Self-sustained EMBR combines the advantages of MFC and MBR in treating wastewater and energy recovery simultaneously. Overall, it is evidenced that MBR and electrokinetic processes have a synergetic enhancement effect in EMBR system.
\end{abstract}

Keywords: membrane bioreactor; electrically-enhanced MBR; membrane fouling; electrophoresis; electrocoagulation

\section{Introduction}

Aboard with industrialization and urbanization that stimulate development of industrial activities and raise living standard, it brings numerous negative impacts to human health and the environment. Over the past decades, unplanned industrialization introduced a massive amount of wastewater into the water bodies resulted in severe water pollution. Typically, wastewater contains suspended solids, dissolved organic matter, inorganic matter, pathogenic microorganisms, and trace metals that might cause skin allergies, kidney dysfunction, cancer, and other diseases if consumed by human directly [1]. This has drawn the enforcement of stringent regulations on wastewater discharge. Besides, the increasing population results in rising demand for clean water, especially during drought season [2]. Hence, awareness of clean water supply shortage and enforcement of wastewater discharge regulations have urged the need of wastewater treatment to reclaim clean water.

Biological treatment is one of the conventional methods to degrade organic contaminants and soluble waste in wastewater by bacterial activity. In general, biological treatment can be divided into aerobic process and anaerobic process depends on the oxygen requirement by bacteria [3]

\footnotetext{
*E-mail address:yh_teow@ukm.edu.my

ISSN: 1791-2377 @ 2017 Eastern Macedonia and Thrace Institute of Technology. All rights reserved. doi:10.25103/jestr.103.18
}

However, biological treatment requires proper maintenance and close monitoring as the activity of bacteria are sensitive to the environment changes. Besides, additional cost is incurred to hire skilled operator for monitoring purpose [4]. In recent years, membrane treatment has emerged as one of the most versatile separation technologies especially for water application and wastewater treatment. Nonetheless, standalone membrane treatment usually cannot produce treated water that meets the stringent effluent standards [1]. Therefore, combination of biological treatment and membrane filtration could provide a feasible alternative to wastewater treatment [5].

Membrane bioreactor (MBR) integrates biological treatment with membrane filtration to achieve improved organics and suspended solids removal. The wastewater is firstly degraded by the activity of microorganisms (i.e. activated sludge) then the treated water is separated from the microorganisms by porous membrane [6]. Figure 1 shows the schematic illustration of a submerged MBR where the membrane is immersed in the bioreactor and air is supplied from underneath of reactor to provide oxygen for bacterial activity and to promote homogeneous mixing. In the conventional biological process, the activated sludge is separated by sedimentation, while in the MBR process, activated sludge is filtered by membrane effectively in a shorter period. In summary, MBR is more effective and advantageous due to its smaller footprint, production of high-quality effluent, minimal waste activated sludge, and it allows fine control of solids retention time (SRT) [7]. 


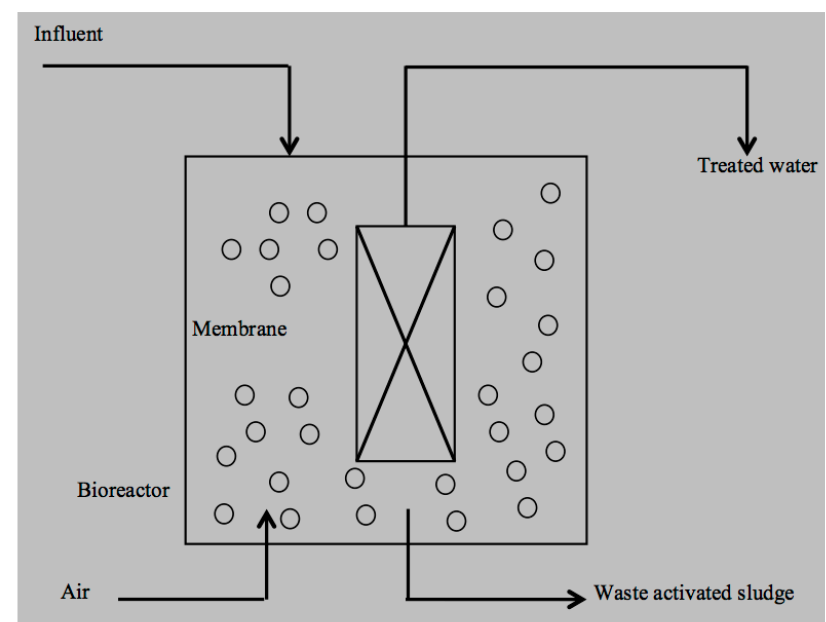

Fig. 1. Schematic illustration of a submerged MBR

Owing to these advantages, MBR has been widely adopted for treating high strength wastewater from municipal [8], tannery [9], textile [10], beverage [11], palm oil [12], and pharmaceutical [13]. However, one of the main drawbacks that hampers large-scale application of MBR is membrane fouling. This is reflected by the number of publication linked to this topic which has escalated rapidly since year 2000 as depicted in Figure 2. Membrane fouling is defined as attachment, accumulation, or adsorption of foulants such as particulates, organic, inorganic, and microorganisms onto membrane surface and/or within the membrane pores [14]. Membrane fouling would affect the overall membrane performance including lower plant productivity, frequent membrane cleaning, increased membrane replacement cost, and higher energy requirement for aeration [15]. To alleviate membrane fouling, several approaches have been investigated including optimization of operating conditions [16, 17], addition of coagulants [18], relaxation and backwashing [19], alteration of membrane properties [20], and modification of MBR configuration [21] Among which applying electricity into MBR to attain electrically-enhanced MBR (EMBR) was researched intensively [22, 23].

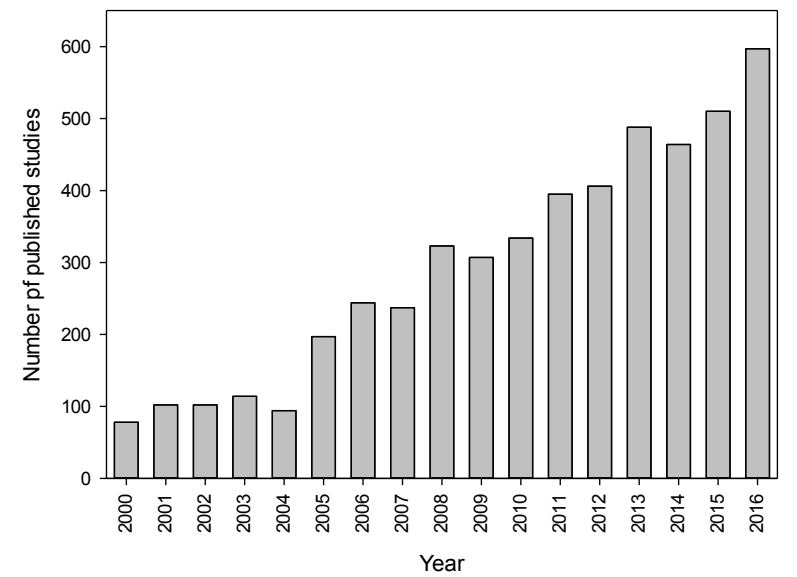

Fig. 2. Number of published research studies linked to the topic of "membrane bioreactor fouling" adopted from ScienceDirect database

This review article is for the first time surveys the past research on EMBR and their addressing for fouling suppression and performance enhancement in wastewater treatment. Besides, this paper also provides insight on the main issues associated with the development of EMBR and renders potential guide for future progress. The paper will start from fundamental study on EMBR including operating mode and design configuration in Section 2. Subsequently, the fouling suppression mechanisms in EMBR including electrophoresis, electrochemical, and electrocoagulation principles are critically reviewed in Section 3. Lastly, Section 4 discusses self-sustained EMBR which is the integration of microbial fuel cell (MFC) and MBR.

\section{Fundamental of EMBR}

In comparison to conventional MBR, EMBR consists additional pair of electrodes (anode and cathode) which supply electricity to the system. The introduction of electricity into EMBR induces several interactions that help to suppress membrane fouling and maintain the integrity of the treatment process. As shown in Figure 3, electricity supplied to EMBR could be from external power source or internally generated by a galvanic cell. Depending on the operating configuration of EMBR, alternative current (AC) or direct current (DC) external electrical source could be supplied to provide the voltage/current necessary for fouling suppression [24]. Whereas, for self-sustained EMBR, internal electricity is generated when the electrons flow from anode to cathode through the external resistance. Hence, there is no additional electric consumption and power facilities involved in self-sustained EMBR [25]. In general, both external power source and self-sustained EMBR employed similar fouling suppression mechanisms.

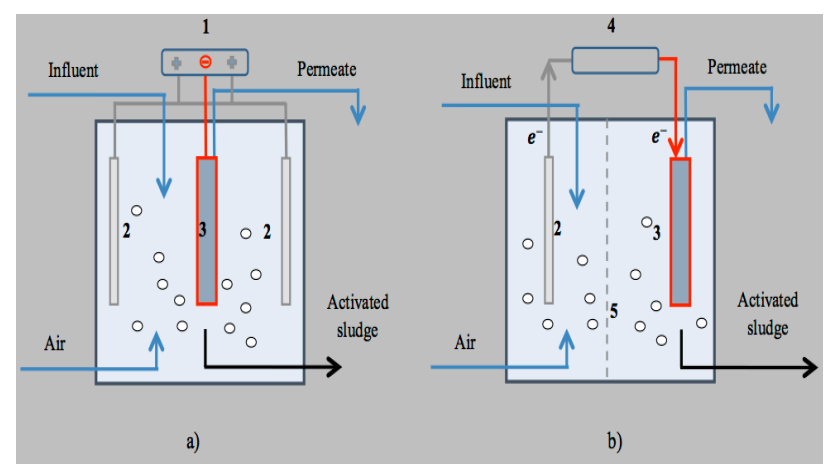

Fig. 3. Schematic diagram of a) external electricity supplied MBR and b self-sustained MBR (1. AC or DC power supply, 2. Anode electrode, 3. Cathode membrane, 4. External resistance, 5. Cation exchange membrane) [26][27]

Generally, membrane in EMBR can be located either within or outside the electric field as depicted in Figure 4. If the membrane is located within the electric field, the cathode is designed as part of the membrane module. The cathode membrane can be easily formed by the attachment of conductive mesh to the filtration membrane. In some cases, membrane modified with conducting additive is used as the electrode membrane in EMBR. Some of the conductive additive such as polypyrrole (PPy), graphene, reduced graphene oxide (rGO) and polyaniline (PANi) are being studied [26, 28, 29, 30]. Besides, the benefits and application of electrically conductive membrane in fouling control had been critically reviewed by Ahmed at al. [31]. On the other hand, the filtration membrane can be an external component to the electrodes pair as shown in Figure 4(b) where the intention of such configuration is to have several zones for different treatment processes [32]. 


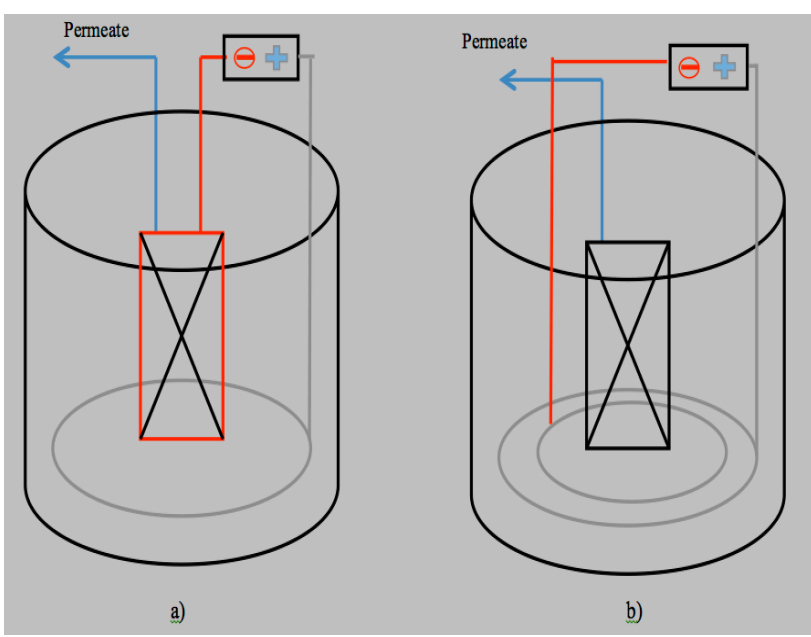

Fig. 4. Configuration of membrane a) within electric field and b) outside electric field in EMBR [32][33]

Efficiency of EMBR greatly depends on the electric field strength and selection of electrodes. By applying voltage or potential difference between the cathode and anode, an electric field is established between the electrodes and can be calculated using Equation 1. As depicted by Equation 1, the strength of electric field depends on the applied voltage and the distance between electrodes which affects the fouling suppression efficiency. It should be highlighted that appropriate electric field should be applied to electrodes without impeding the microorganisms' metabolism. According to a study conducted by Alshawabkeh et al. [34], optimum DC range for aerobic microbes is between 0.28 $\mathrm{V} / \mathrm{cm}$ to $1.14 \mathrm{~V} / \mathrm{cm}$. They observed that impact of DC electric field below $0.28 \mathrm{~V} / \mathrm{cm}$ was insignificant for pollutant reduction while greater than $1.4 \mathrm{~V} / \mathrm{cm}$ will disrupt the metabolism of microorganism.

$E=\frac{V}{d}$

Where $E$ is the electric field $(\mathrm{V} / \mathrm{cm}), V$ is the electric voltage $(\mathrm{V})$, and $d$ is the distance between electrodes $(\mathrm{cm})$.

As shown in Figure 5, selection of electrode determines the nature of electrokinetic process happened in EMBR such as electrophoresis, electrocoagulation, and electrochemical oxidation. For electrocoagulation, active anode is used to supply cation coagulants. The most commonly used active anodes are aluminium $(\mathrm{Al})$ and iron $(\mathrm{Fe})$. For instance using aluminium anode, $\mathrm{Al}^{3+}$ ions are released at the anode and dissolved into the wastewater, forming aluminium hydroxides, $\mathrm{Al}(\mathrm{OH})_{3}$ which serve as cation coagulants. Subsequently, the cation coagulants will neutralize the electrostatic charges on pollutants and enable agglomeration to form flocs. Lastly, the heavier flocs precipitated down from mixed liquor by gravity to form sludge. This reduces the accumulation of pollutants on the membrane surface which lowers the fouling propensity. Type of dissolved anode material and concentration are important for microbial viability where moderate metal concentration could facilitate enzymatic digestion of bacteria while high metal concentration could inhibit the growth of bacteria [33]. At the cathode, water is reduced readily to form hydrogen gas and hydroxyls which increase the $\mathrm{pH}$ consequently. Usually, intermittent (on/off) DC is supplied to maintain the recommended range of $\mathrm{pH}$ from 5 to 9 for microorganisms [34]. The mechanisms are summarized from Equation 2 to Equation $4[35,36]$.

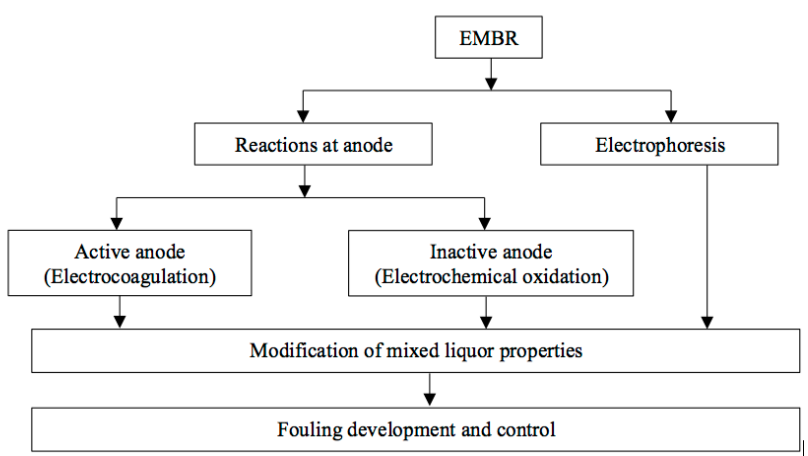

Fig. 5. Fouling suppression mechanism by electrokinetic process in EMBR [32]

Anode:

$A l \rightarrow A l^{3+}+3 e^{+}$

In wastewater:

$\mathrm{Al}^{3+}+3 \mathrm{H}_{2} \mathrm{O} \rightarrow \mathrm{Al}(\mathrm{OH})_{3}+3 \mathrm{H}^{+}$

Cathode:

$2 \mathrm{H}_{2} \mathrm{O}+2 e^{+} \rightarrow \mathrm{H}_{2}+2 \mathrm{OH}^{-}$

Unlike electrocoagulation, electrophoresis is independent from anode material. It is a phenomenon where the movement of charged particles in solution is influenced by an applied electric field. In EMBR, electrophoresis occurs when the movement of macromolecules with different size and charge is put under the influence of a spatially uniform electric field generated between electrodes. As aforementioned, when the cathode acts as a conducting membrane, the supply of electricity in the EMBR system will impart negative charge on the membrane surface. The additional negative charge on membrane surface helps in repelling the negatively charged foulants such as natural organic matter (NOM) [37]. Furthermore, the electric field generated between the cathode membrane and inactive anode drives the foulants to move away from membrane surface towards the anode by electrophoresis as depicted in Figure 6. Hence, electrophoresis creates strong repulsion of foulants from membrane surface and results in the formation of loose filter cake layer. The loose filter cake layer can be easily cleaned by air scouring to recover the membrane flux [38].

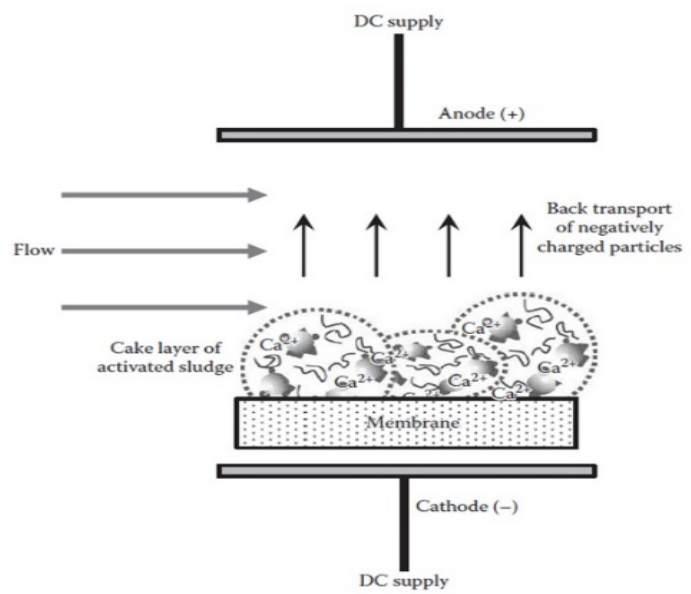

Fig. 6. Schematic illustration of foulants' back transport under DC induction electric field [6] 
Application of voltage exceeding the water breakdown threshold will initiate the electrochemical reaction at anode and cathode. Using inactive anode, water is decomposed into hydroxyl radical $(\cdot \mathrm{OH})$ which is the second strongest oxidant after fluorine with a high standard potential $\left(\mathrm{E}^{\circ}=\right.$ $2.80 \mathrm{~V})$. Then, $\mathrm{OH}$ will degrade pollutants through oxidation to form oxidized pollutants. The mechanism of $\cdot \mathrm{OH}$ generation and pollutant electroxidation are shown in Equation 5 and Equation 6 [39].

Anode:

$$
\begin{aligned}
& \mathrm{H}_{2} \mathrm{O} \rightarrow \cdot \mathrm{OH}+\mathrm{H}^{+}+e^{+} \\
& \cdot \mathrm{OH}+\mathrm{R} \rightarrow \mathrm{OR}+\mathrm{H}^{+}+e^{+}
\end{aligned}
$$

Where $R$ is the pollutant and $O R$ is the oxidized polluant.

Whereas, at the cathode, oxygen is reduced to form hydrogen peroxide, $\mathrm{H}_{2} \mathrm{O}_{2}$, a strong oxidant $\left(\mathrm{E}^{\circ}=1.763 \mathrm{~V}\right)$ to oxidize various organic pollutants and for in-situ membrane cleaning as shown in Equation 7 [40, 41]. As reported by Plakas et al. [42], $\mathrm{H}_{2} \mathrm{O}_{2}$ production is affected by electrode materials, applied potential, $\mathrm{pH}$, and ionic strength. As such, some catalysts such as expensive platinum and nitrogen-doped carbon are employed as cathode material for favor electrochemically-selective production of $\mathrm{H}_{2} \mathrm{O}_{2}$ [43].

Cathode:
$\mathrm{O}_{2}+2 \mathrm{H}^{+}+2 e^{+} \rightarrow \mathrm{H}_{2} \mathrm{O}_{2}$

When electric field is applied in EMBR, electrokinetic process alters the properties of mixed liquor such as soluble microbial products (SMP) and microorganisms which contribute to the different fouling mechanism [32]. The selection of electrokinetic process should depend on feed quality, effluent discharge standards, microorganisms viability, sludge disposal standards, operating cost, and capital cost. In some cases, electrocoagulation may provide better pollutant removal and fouling suppression but it requires higher operating cost due to the replacement of active anode in long-run.

\section{Fouling suppression in EMBR attributed to different electrokinetic process}

\subsection{Electrophoresis and electrochemical}

In this section, electrophoresis and electrochemical processes are discussed together as both processes employ inactive electrodes in EMBR. As shown in Table 1, stainless steel, platinized titanium, platinum, graphite, lead oxide $\left(\mathrm{PbO}_{2}\right)$, and carbon are the most common inactive electrodes that employed in EMBR. However, $\mathrm{PbO}_{2}$ is the most attractive electrode owing to its excellent electrical conductivity, favorable over potential, high chemical inertness, low cost, and outstanding electrocatalytic performance [39].

\begin{tabular}{|c|c|c|c|c|c|}
\hline Anode & Cathode & Application & $\begin{array}{c}\text { Reactor } \\
\text { Volume } \\
\text { (L) }\end{array}$ & Electricity supply & Reference \\
\hline Stainless steel & $\begin{array}{l}\text { Stainless steel } \\
\text { assembled with } \\
\text { membrane }\end{array}$ & Urban sewage water & 40.5 & $\begin{array}{c}\text { Continuous DC. } 5 \mathrm{~V} / \mathrm{cm}- \\
30 \mathrm{~V} / \mathrm{cm}\end{array}$ & Chen et al. [22] \\
\hline Stainless steel & $\begin{array}{l}\text { Stainless steel } \\
\text { assembled with } \\
\text { membrane }\end{array}$ & Urban sewage water & 40.5 & Intermittent DC. $20 \mathrm{~V} / \mathrm{cm}$ & Chen et al. [40] \\
\hline $\begin{array}{l}\text { Platinized titanium, } \\
\qquad \mathrm{PbO}_{2} \text {, graphite }\end{array}$ & Platinized titanium & Landfill leachates & 20 & $\begin{array}{c}\text { Continuous DC. } 0.3 \mathrm{~A}- \\
2.4 \mathrm{~A}\end{array}$ & Feki et al. [41] \\
\hline Platinized titanium & Stainless steel & Landfill leachates & 14 & $\begin{array}{c}\text { Continuous DC. } 0.1 \mathrm{~A}- \\
0.8 \mathrm{~A}\end{array}$ & Aloui et al. [42] \\
\hline Platinum & Platinum & Synthetic sewage water & 10 & $\begin{array}{c}\text { Continuous or intermittent } \\
\text { DC. } 4 \mathrm{~V} / \mathrm{cm}-6 \mathrm{~V} / \mathrm{cm}\end{array}$ & Akamatsu et al. [43] \\
\hline Carbon cloth & Carbon cloth & Silica suspension & 20 & $\begin{array}{l}\text { Continuous or intermittent } \\
\text { DC. } 12 \mathrm{~V} / \mathrm{cm}-32 \mathrm{~V} / \mathrm{cm}\end{array}$ & Akamatsu et al. [44] \\
\hline Stainless steel & $\begin{array}{l}\text { Copper assembled } \\
\text { with membrane }\end{array}$ & Synthetic wastewater & 10 & $\begin{array}{c}\text { Intermittent } \\
\text { DC. } 0.036 \mathrm{~V} / \mathrm{cm}-0.073 \\
\mathrm{~V} / \mathrm{cm}\end{array}$ & Liu et al. [45] \\
\hline Stainless steel & $\begin{array}{l}\text { Conductive } \\
\text { membrane }\end{array}$ & Synthetic wastewater & 12 & $\begin{array}{c}\text { Continuous } \\
\text { DC. } 0.2 \mathrm{~V} / \mathrm{cm}-0.4 \mathrm{~V} / \mathrm{cm}\end{array}$ & Liu et al. [46] \\
\hline Stainless steel & $\begin{array}{l}\text { Conductive } \\
\text { membrane }\end{array}$ & Yeast suspension & 4 & $\begin{array}{l}\text { Continuous } \\
\text { DC. } 1 \mathrm{~V} / \mathrm{cm}\end{array}$ & Liu et al. [47] \\
\hline Stainless iron & $\begin{array}{l}\text { Conductive } \\
\text { membrane }\end{array}$ & Yeast suspension & 2.7 & $\begin{array}{c}\text { Continuous } \\
\text { DC. } 0.2 \mathrm{~V} / \mathrm{cm}\end{array}$ & Li et al. [48] \\
\hline \multicolumn{2}{|c|}{ Titanium assembled with membrane } & Biomass suspension & N/A & $\begin{array}{c}\text { Continuous } \\
\text { AC } 60 \mathrm{~V}-160 \mathrm{~V}\end{array}$ & Hawari et al. [49] \\
\hline Carbon cloth & $\begin{array}{c}\text { Stainless steel } \\
\text { assembled with } \\
\text { membrane }\end{array}$ & Synthetic wastewater & 0.63 & $\begin{array}{l}\text { Continuous } \\
\text { DC. } 2 \mathrm{~V} / \mathrm{cm}\end{array}$ & Huang et al. [37] \\
\hline $\begin{array}{c}\text { Stainless steel or } \\
\text { titanium }\end{array}$ & $\begin{array}{r}\text { Titanium assembled } \\
\text { with membrane }\end{array}$ & Synthetic wastewater & 10 & $\begin{array}{l}\text { Continuous } \\
\text { DC. } 0.1 \mathrm{~A}\end{array}$ & Zhang et al. [28] \\
\hline Titanium/ $\mathrm{PbO}_{2}$ & Stainless steel & Phenol suspension & 170 & $\begin{array}{c}\text { Intermittent } \\
\text { DC. } 0.7 \mathrm{~V} / \mathrm{cm}\end{array}$ & Wang et al. [50] \\
\hline
\end{tabular}

Table 1. Summary of EMBR based on electrophoresis and electrochemical principle

The pioneer work on EMBR study based on electrophoresis and electrochemical principle was initiated by Chen et al. [22] where they first applied continuous DC in submerged EMBR to treat urban sewage water. They found that the membrane flux increased substantially as electric field raised from $15 \mathrm{~V} / \mathrm{cm}$ to $20 \mathrm{~V} / \mathrm{cm}$. This is 
attributed to the strengthened electrophoresis impact that resulted in the formation of thinner sedimentation layer which exerted lower filtration resistance to the permeation of water. However, the membrane flux showed no further increment when electric field increased beyond the critical point $(20 \mathrm{~V} / \mathrm{cm})$ as they concluded that increased speed of electrophoresis and diffusion movement of foulants from the membrane surface was much faster than permeation drag movement onto the membrane surface and hence fouling was no longer a limiting factor in membrane flux. Thereafter, Chen et al. [44] further investigated the effect of intermittent (on/off) DC in EMBR where the research group discovered that the membrane flux recovered immediately when intermittent DC electric field (10 seconds) was applied. This is because intermittent electric field created a pulse intensity that is strong enough to lift and remove the deposited foulants on the membrane surface and consequently recovered the membrane flux. Their study suggested that the membrane flux recovery under intermittent $\mathrm{DC}$ is comparable with that of continuous DC under similar electric field strength and hence deduced that intermittent DC mode could save more energy by regulating the optimal DC exposure time.

Similar finding was obtained by Akamatsu et al. [45] using external cross-flow membrane module under electric field of $6 \mathrm{~V} / \mathrm{cm}$ and switched on and off every $90 \mathrm{~s}$ in EMBR system. Followed by the success of this study, Akamatsu et al. [46] replaced the platinum electrode with lower cost carbon cloth which intent to bring beneficial for large-scale application. However, as compared to platinum electrode, higher electric current is required for carbon cloth electrode to induce stronger electric field for fouling suppression as the electroconductivity of carbon cloth is lower than platinum [47]. Hence, this had initiated the development of low-cost electrically conductive membrane for EMBR.

Liu et al. [48] developed a novel conductive membrane as cathode by embedding copper wires inside the flat sheet membrane module. The integration of metallic cathode and membrane to form conductive membrane as cathode consumes less space and increases the effective reactor volume hence provides longer biomass retention time for bacterial digestion. They concluded that minute electric field $(0.036 \mathrm{~V} / \mathrm{cm}$ and $0.073 \mathrm{~V} / \mathrm{cm})$ was sufficient to reduce cake layer thickness and pore blocking caused by synthetic foulants. Afterward, Liu et al. [28] continued in synthesizing conductive membrane by modifying polyester filter cloth with PPy via in-situ polymerization of pyrrole and sodium dodecyl benzene sulfonate (SDBS). Figure 7 shows that with the doping of more electrically conductive PPy onto the membrane surface around pore entrance, stronger electric field was generated and hence exerted stronger repulsion forces to repel the foulants. Consequently, the conductive membrane stands a better chance in treating synthetic wastewater with lower fouling propensity. Encouraged by the finding from this study, more research work on the development of low-cost conductive membrane using rGO and PANi in EMBR application have been conducted $[26][30][49]$. The results showed that the conductive membrane modified by hybrid GO-PANi has higher permeate flux and better antifouling property at low electric field $(0.2 \mathrm{~V} / \mathrm{cm})$ as compared to individual $\mathrm{GO}$ and $\mathrm{PANi}$, respectively. This is attributed by two-dimensional $\mathrm{rGO}$ which provides large surface area and improves the stability of PANi on the filter cloth, thus allows better electron mobility and lower specific electric resistance.

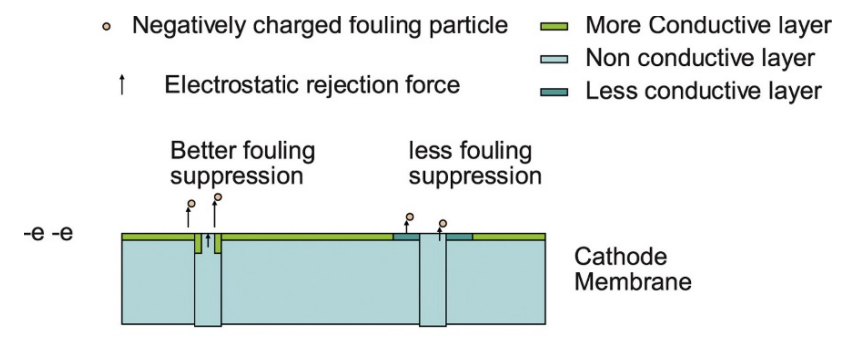

Fig. 7. Fouling suppression mechanism by conductive membrane [49]

In more recent publications, Huang et al. [41] discovered that electric field has not only enhanced the electrostatic repulsive force between foulants and membrane surface but also produced $\mathrm{H}_{2} \mathrm{O}_{2}$ from electrochemical reduction by oxygen at the cathode membrane assembled with stainless steel. Figure 8 shows that $\mathrm{H}_{2} \mathrm{O}_{2}$ as strong oxidant will further oxidize the hydroxyl groups of polysaccharides to carboxyl groups. As a result, it increases the negative charge of polysaccharides, hence enhanced the repulsive force between oxidized polysaccharides and membranes. The research group found that the fouling rate of EMBR is two times lower using conductive membrane with $2 \mathrm{~V} / \mathrm{cm}$ of electric field compared to control MBR. Later, Wang et al. [50] treated phenol wastewater by applying DC field between immersed catalytic electrodes in EMBR. Catalytic titanium $/ \mathrm{PbO}_{2}$ anode generates $\cdot \mathrm{OH}$ which successfully degrades phenol to 2,6-di-tert-butyl-p-benzoquinone, a less harmful intermediate product under the coupling effects of bio-electrochemical reaction. Besides, this value-added intermediate product can be recycled and used in the pharmaceutical industry.

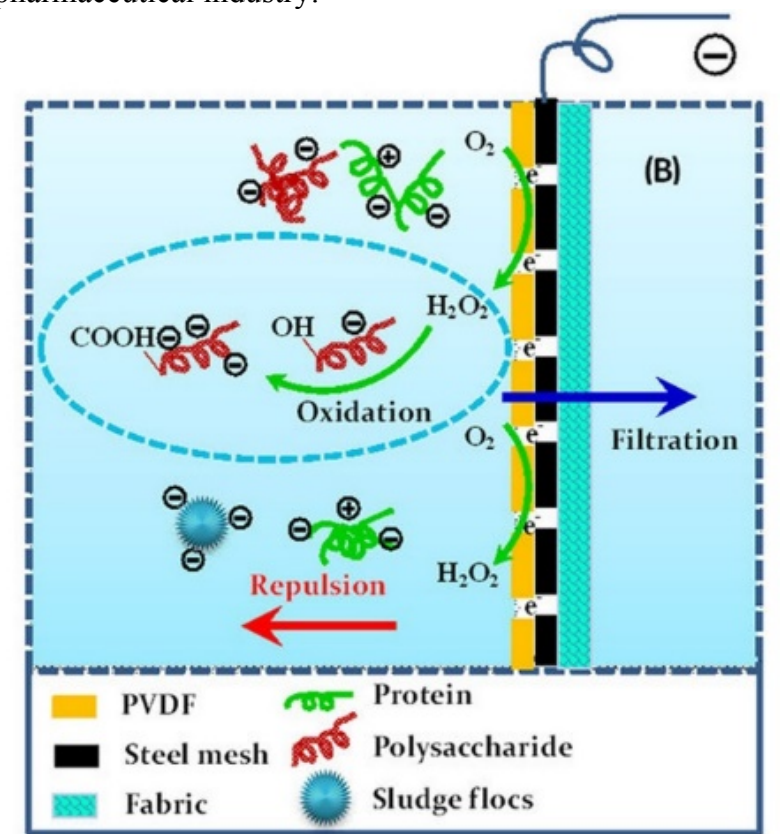

Fig. 8. Schematic illustration of fouling suppression mechanism by electrophoresis and electrochemical reactions [41]

The potential application of AC power source in EMBR was explored by Hawari et al. [51]. Unlike DC electric field, dielectrophoretic (DEP) force is generated in an inhomogeneous electrical field as shown in Figure 9. In an inhomogeneous electrical field, different forces are acting on both sides of particle resulted a net DEP force regardless of the particle's charge. High electric voltage will increases the DEP force which in return suppressed the membrane fouling. However, lower permeate flux was observed at high 
frequency $(1000 \mathrm{~Hz})$ due to the electrothermal effect (ETE) where heat was accumulated in the system thus impaired the membrane's structure such as porosity and pore size. Therefore, an optimized DEP EMBR system should employ $\mathrm{AC}$ electric field with high voltage at low frequency.
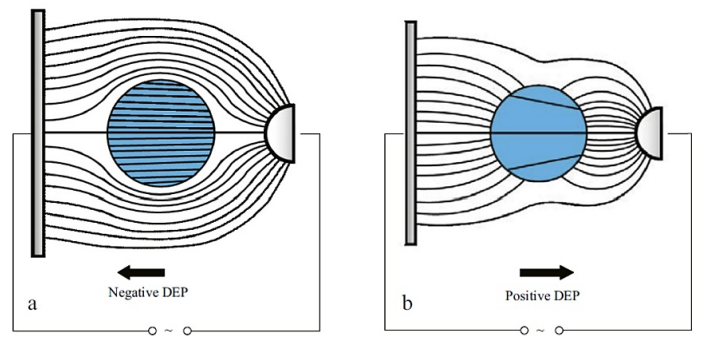

Fig. 9. Schematic illustration of DEP force on particle motion direction [51]

To sum up, electrophoresis and electrochemical principle have successfully suppressed membrane fouling by pushing foulants away from deposited on the membrane surface and degraded the foulants simultaneously. However, electrophoresis requires higher energy consumption ( 3 times higher than electrocoagulation) to attain the similar degree of fouling suppression [32]. Besides, continuous monitoring on toxicity of degraded pollutant is crucial to ensure the practicability of electrochemical oxidation. Due to these limitations, electrophoresis and electrochemical oxidation are usually limited for treating low strength wastewater that does not require high-quality effluent standards.

\subsection{Electrocoagulation}

Electrocoagulation not only able to reduce foulant adhesion on the membrane surface, but also enhance the removal efficiency of metals, colloids, and solid particles. Electrolytic dissolution of active metal anode produces cation coagulants that bind the impurities together. As tabulated in Table 2, $\mathrm{Al}$ and $\mathrm{Fe}$ electrodes are most commonly employed in EMBR. The quantity of cation generated from the dissolution of active metal anode has significant effect on the efficiency of electrocoagulation. Ideally, the electrically generated coagulant cations $\left(\mathrm{M}^{+}\right)$ will formed highly stabilized colloids with alginate and settled down as sludge. However, when the generated $\mathrm{M}^{+}$is higher than the critical coagulant cations demand $\left(\mathrm{M}_{\text {crit }}{ }^{+}\right)$, the fouling propensity will increase significantly due to the formation of coagulant oxide which blocks the water from passage through the membrane.

Table 2. Summary of EMBR based on electrocoagulation principle

\begin{tabular}{|c|c|c|c|c|c|}
\hline Anode & Cathode & Application & $\begin{array}{l}\text { Reactor volume } \\
\text { (L) }\end{array}$ & Electricity supply & Reference \\
\hline $\mathrm{Al}$ & Not mentioned & Synthetic wastewater & 3.72 & Continuous DC. $1.82 \mathrm{~V} / \mathrm{cm}$ & Wei et al. [23] \\
\hline Al & $\mathrm{Fe}$ & Synthetic wastewater & 13.4 & Intermittent DC. $1 \mathrm{~V} / \mathrm{cm}$ & $\begin{array}{l}\text { Bani-Melhem et al. } \\
\text { [52] }\end{array}$ \\
\hline $\mathrm{Fe}$ & $\mathrm{Fe}$ & Synthetic wastewater & 20 & $\begin{array}{l}\text { Intermittent DC. } 1 \mathrm{~V} / \mathrm{cm}-6 \\
\mathrm{~V} / \mathrm{cm}\end{array}$ & $\begin{array}{l}\text { Bani-Melhem and } \\
\text { Elektorowicz }\end{array}$ \\
\hline $\mathrm{Al}$ & Stainless steel & Synthetic wastewater & 8 & Intermittent DC. $15 \mathrm{~A} / \mathrm{m}^{2}$ & Ibeid et al. [53] \\
\hline $\mathrm{Fe}$ & $\mathrm{Fe}$ & Synthetic wastewater & 13.4 & Intermittent DC. $1 \mathrm{~V} / \mathrm{cm}$ & $\begin{array}{l}\text { Bani-Melhem and } \\
\text { Elektorowicz }\end{array}$ \\
\hline $\mathrm{Al}$ & Not mentioned & Sewage wastewater & 740 & Intermittent DC. N/A & $\begin{array}{l}\text { Elektorowicz et al. } \\
\text { [55] }\end{array}$ \\
\hline $\mathrm{Al}$ & Not mentioned & Municipal wastewater & 235 & Intermittent DC. $12 \mathrm{~A} / \mathrm{m}^{2}$ & Hasan et al. [56] \\
\hline $\mathrm{Al}$ & $\mathrm{Al}$ & Sewage wastewater & 8.5 & Intermittent DC. $1.2 \mathrm{~V} / \mathrm{cm}$ & Wei et al. [57] \\
\hline $\begin{array}{l}\text { Stainless steel/ } \\
\text { Fe }\end{array}$ & $\begin{array}{l}\text { Conductive } \\
\text { membrane }\end{array}$ & Synthetic wastewater & 12 & Intermittent DC. $0.2 \mathrm{~V} / \mathrm{cm}$ & Liu et al. [58] \\
\hline $\mathrm{Fe}$ & $\begin{array}{l}\text { Conductive } \\
\text { membrane }\end{array}$ & Synthetic wastewater & 18.2 & $\begin{array}{l}\text { Intermittent DC. } 1 \mathrm{~mA}-5 \\
\mathrm{~mA}\end{array}$ & Liu et al. [59] \\
\hline $\mathrm{Al}$ & $\mathrm{Al}$ & Grey water & 3.63 & Intermittent DC. $2 \mathrm{~V} / \mathrm{cm}$ & $\begin{array}{l}\text { Bani-Melhem and } \\
\text { Smith [60] }\end{array}$ \\
\hline $\mathrm{Al}$ & Stainless steel & Synthetic wastewater & 1 & $\begin{array}{l}\text { Intermittent DC. } 0.5 \mathrm{~V} / \mathrm{cm} \text { to } \\
1.5 \mathrm{~V} / \mathrm{cm}\end{array}$ & Ibeid et al. [61] \\
\hline $\mathrm{Fe}$ & $\begin{array}{l}\text { Conductive } \\
\text { membrane }\end{array}$ & Methylene blue & N/A & Intermittent DC. $1 \mathrm{~V} / \mathrm{cm}$ & Zhao et al. [29] \\
\hline $\mathrm{Al}$ & Stainless steel & Municipal wastewater & 235 & $\begin{array}{l}\text { Intermittent } \\
\text { DC. } 12 \mathrm{~A} / \mathrm{m}^{2}\end{array}$ & Hasan et al. [62] \\
\hline $\mathrm{Fe}$ & $\mathrm{Fe}$ & Industrial wastewater & 32 & Continuous DC. $10 \mathrm{~mA} / \mathrm{cm}^{2}$ & $\begin{array}{l}\text { Hosseinzadeh et al. } \\
\text { [63] }\end{array}$ \\
\hline $\mathrm{Al}$ & Stainless steel & Municipal wastewater & 31.5 & Not mentioned & Giwa et al. [36] \\
\hline $\mathrm{Al}$ & $\mathrm{Fe}$ & Synthetic wastewater & 8 & $\begin{array}{l}\text { Continuous/ intermittent DC. } \\
5 \mathrm{~A} / \mathrm{m}^{2} \text { to } 35 \mathrm{~A} / \mathrm{m}^{2}\end{array}$ & Ibeid et al. [64] \\
\hline $\mathrm{Fe}$ & Stainless steel & Synthetic wastewater & 13.5 & $\begin{array}{l}\text { Continuous/ intermittent DC. } \\
5 \mathrm{~A} / \mathrm{m}^{2} \text { to } 23 \mathrm{~A} / \mathrm{m}^{2}\end{array}$ & Tafti et al. [65] \\
\hline
\end{tabular}

The pioneer work on EMBR study based on electrocoagulation principle was first led by Elektorowicz et al. [66]. Elektorowicz et al. [66] had successfully file a patent of novel wastewater treatment system named submerged membrane electro-bioreactor (SMEBR) which integrates biodegradation, electrocoagulation, electro-sedimentation, and membrane filtration as shown in Figure 10. The results showed that SMEBR had reduced
$52 \%$ membrane fouling and better chemical oxygen demand (COD) and phosphorus $\left(\mathrm{PO}_{4} \mathrm{P}\right)$ removal compared to conventional MBR. Subsequently, Elektorowicz et al. [55] tested the operation of SMEBR in pilot scale using real sewage wastewater on continuous basis. Excellent removal of COD (92\%), ammonia (99\%), and phosphorus (99\%), as well as marginal membrane fouling were obtained after 45 days of operation. However, their studies found that both 
effluent and sludge contain about $21.43 \%$ and $23.81 \%$ of $\mathrm{Al}^{3+}$ due to the electrolytic dissolution at anode which could be a concern in some countries as $\mathrm{Al}$ is categorized as scheduled waste [67].

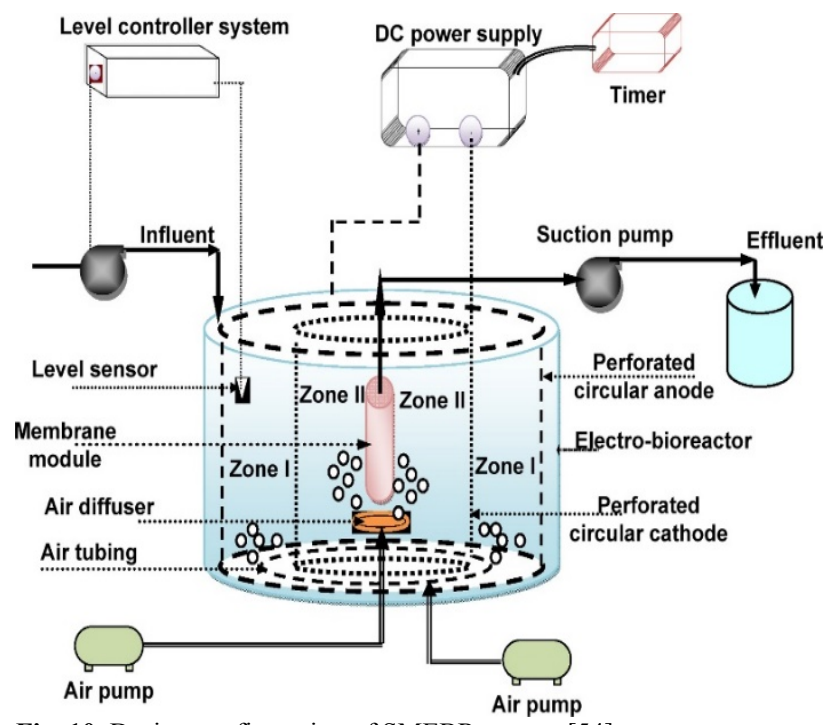

Fig. 10. Design configuration of SMEBR system [54]

To understand the fundamental of electrocoagulation in suppressing membrane fouling, Ibeid et al. [53] conducted an experiment to investigate the effect of electrocoagulation on SMP and volatile suspended solids (VSS) towards membrane fouling. The study proved that SMP has more significant effect than VSS on membrane fouling control as the former tends to attract water molecules through hydrogen bonds thus forming a more compact cake layer with reduced sludge filterability. As cation coagulant reacts with the pollutants from wastewater to form sludge in SMEBR, it is crucial to study the sludge properties under the effect of electrocoagulation. Ibeid et al. [61] found that electrocoagulation induced by DC field affects the sludge properties including concentration of SMP, colloidal organics, soluble organics, humic substances, zeta potential, floc size, and sludge filterability. The degree of these changes vary based on the current density, electrical mode (exposure time), and biomass concentration.

Similar to electrophoresis and electrochemical principle, conductive membrane was also introduced replace external cathode together with active electrode to induce electrocoagulation in SMEBR. Liu et al. [58] have discovered that SMEBR equipped with PPy modified filter cloth as cathode membrane demonstrated better performance in term of fouling control and effluent water quality at a very low electric field $(0.2 \mathrm{~V} / \mathrm{cm})$. Subsequently, Zhao et al. [29] integrated electrocoagulation and E-Fenton oxidation (electrocatalysis) in treating methylene blue (MB) using graphene/PPy modified membrane. As shown in Figure 11, $\mathrm{H}_{2} \mathrm{O}_{2}$ generated by oxygen reduction at cathode membrane, forming Fenton reagent with appropriate conditions (electrolyte, dissolved iron cations $\left(\mathrm{Fe}^{2+}\right), \mathrm{pH}$, and electric field). It was demonstrated integrated synergetic effect of both electrocoagulation and electrocatalysis has significantly reduced $\mathrm{MB}$ up to $90 \%$ showing the potential application of SMEBR to treat textile wastewater.

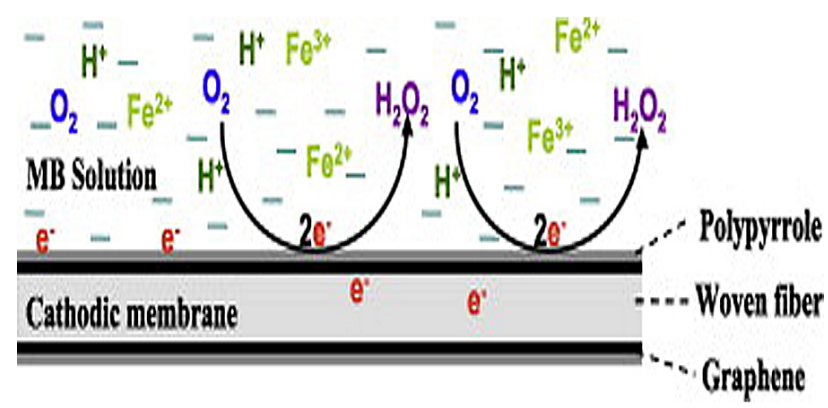

Fig. 11. Schematic illustration of $\mathrm{MB}$ degradation by E-Fenton oxidation [29]

\section{Self-sustained EMBR}

A MFC is a promising approach to recover energy from wastewater by converting energy in organic compounds into electricity by the microbial-catalyzed reaction. The basic working mechanism of MFC is similar to galvanic cell which involves the bacterial metabolic activity to generate electrons $\left(\mathrm{e}^{-}\right)$and protons $\left(\mathrm{H}^{+}\right)$in anode chamber. The electrons are transferred to cathode (electron acceptor) in cathode chamber via the external resistance. Ion exchange membrane (IEM) allows the migration of proton from anode chamber to cathode chamber to close the circuit as shown in Figure 12. It is crucial to maintain anaerobic zone in anodic chamber while aerobic zone in cathodic chamber to optimize the energy recovery. This is to prevent the consumption of electron by oxygen at anode before transferring to cathode [68]. In general, MFC is associated with poor effluent quality due to limited biomass retention. As such, MFC is usually incorporated into existing wastewater treatment processes to improve its applicability [69]. Self-sustained EMBR is the integration of MFC-MBR system for simultaneous wastewater treatment and energy recovery in which the cathode electrode in MFC is replaced with MBR to separate treated water from activated sludge. Most of the recent studies on the self-sustained EMBR are focus on configuration design and nature of electrodes as tabulated in Table 3.

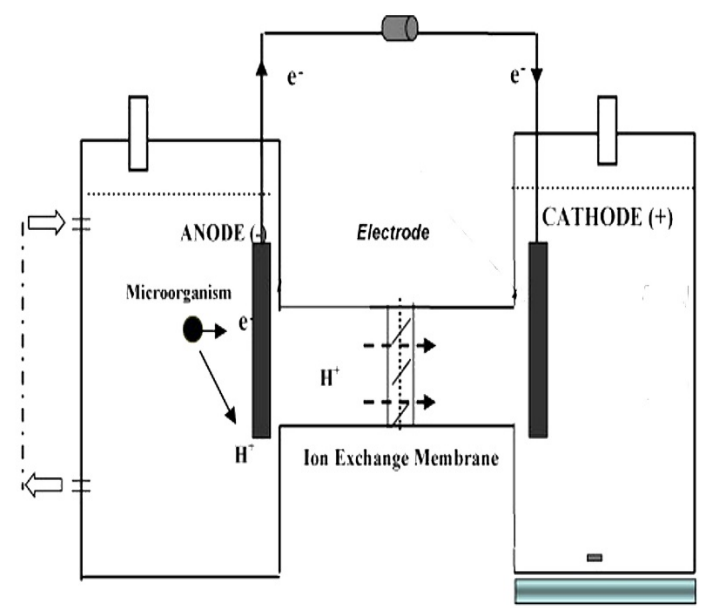

Fig. 12. Schematic diagram of dual chambered MFC [70] 
Table 3. Summary of self-sustained EMBR

\begin{tabular}{|c|c|c|c|c|c|}
\hline $\begin{array}{l}\text { Anode } \\
\text { chamber }\end{array}$ & $\begin{array}{l}\text { Cathode } \\
\text { chamber }\end{array}$ & $\begin{array}{l}\text { Self-sustained EMBR } \\
\text { configuration }\end{array}$ & Application & Power density & Reference \\
\hline $\begin{array}{l}\text { Granular graphite with } \\
\text { a graphite rod }\end{array}$ & $\begin{array}{l}\text { Stainless steel mesh } \\
\text { with biofilm }\end{array}$ & \multirow[t]{3}{*}{$\begin{array}{l}\text { Tubular cathodic membrane } \\
\text { and anode chambers were } \\
\text { submerged in a column reactor. }\end{array}$} & \multirow[t]{3}{*}{ Synthetic wastewater } & \multirow[t]{3}{*}{$4.35 \mathrm{~W} / \mathrm{m}^{3}$} & \multirow[t]{3}{*}{ Wang et al. [71] } \\
\hline Anaerobic & Aerobic & & & & \\
\hline $210 \mathrm{~mL}$ & $2.3 \mathrm{~L}$ & & & & \\
\hline Activated carbon filber & $\begin{array}{l}\text { Carbon felt with nylon } \\
\text { mesh }\end{array}$ & \multirow[t]{3}{*}{$\begin{array}{l}\text { Aeration tank of MBR was } \\
\text { used as cathode chamber. }\end{array}$} & \multirow[t]{3}{*}{ Synthetic wastewater } & \multirow[t]{3}{*}{$6 \mathrm{~W} / \mathrm{m}^{3}$} & \multirow[t]{3}{*}{ Wang et al. [72] } \\
\hline Anaerobic & Aerobic & & & & \\
\hline $80 \mathrm{~mL}$ & $20 \mathrm{~L}$ & & & & \\
\hline Iron & Stainless steel & \multirow{3}{*}{$\begin{array}{l}\text { Anode chamber was flanked by } \\
\text { two aerobic cathode chambers. }\end{array}$} & \multirow[t]{3}{*}{ Synthetic wastewater } & \multirow[t]{3}{*}{$29.99 \mathrm{~mW} / \mathrm{m}^{2}$} & \multirow[t]{3}{*}{ Song et al. [73] } \\
\hline Anaerobic biofilm & $\begin{array}{l}\text { Aerobic Activated } \\
\text { sludge }\end{array}$ & & & & \\
\hline N/A & $\mathrm{N} / \mathrm{A}$ & & & & \\
\hline Carbon felt & Carbon felt & \multirow{3}{*}{$\begin{array}{l}\text { MFC was combined with } \\
\text { side-stream tubular membrane } \\
\text { cross-flow filtration system. }\end{array}$} & \multirow[t]{3}{*}{ Synthetic wastewater } & \multirow[t]{3}{*}{$0.04 \mathrm{~W} / \mathrm{m}^{2}$} & \multirow[t]{3}{*}{ Wang et al. [74] } \\
\hline Anaerobic & Aerobic & & & & \\
\hline $2.5 \mathrm{~L}$ & $2.5 \mathrm{~L}$ & & & & \\
\hline $\begin{array}{l}\text { Granular graphite with } \\
\text { a graphite rod }\end{array}$ & $\begin{array}{l}\text { Stainless steel mesh } \\
\text { with biofilm }\end{array}$ & \multirow[t]{3}{*}{$\begin{array}{l}\text { Tubular cathodic membrane } \\
\text { and anode chambers were } \\
\text { submerged in a column reactor } \\
\text { similar to [71] }\end{array}$} & \multirow[t]{3}{*}{ Synthetic wastewater } & \multirow[t]{3}{*}{$1.43 \mathrm{~W} / \mathrm{m}^{3}$} & \multirow[t]{3}{*}{ Wang et al. [75] } \\
\hline Anaerobic & Aerobic & & & & \\
\hline $210 \mathrm{~mL}$ & $2.3 \mathrm{~L}$ & & & & \\
\hline Iron & Conductive membrane & \multirow[t]{3}{*}{$\begin{array}{l}\text { Both anode and cathode were } \\
\text { immersed in aeration tank. }\end{array}$} & \multirow[t]{3}{*}{ Synthetic wastewater } & \multirow[t]{3}{*}{$2.6 \mathrm{~mW} / \mathrm{m}^{2}$} & \multirow[t]{3}{*}{ Liu et al. [27] } \\
\hline \multicolumn{2}{|c|}{ Aerobic } & & & & \\
\hline \multicolumn{2}{|c|}{$18.2 \mathrm{~L}$} & & & & \\
\hline Carbon cloth & $\begin{array}{l}\text { PTFE membrane with } \\
10 \% \text { platinum }\end{array}$ & $\begin{array}{c}\text { MFC was operated with a } \\
\text { direct feed of activated sludge }\end{array}$ & Synthetic wastewater & $51 \mathrm{~mW} / \mathrm{m}^{2}$ & Su et al. [76] \\
\hline Anaerobic & Aerobic & from the MBR. Then, the & & & \\
\hline $200 \mathrm{~mL}$ & $8 \mathrm{~L}$ & $\begin{array}{l}\text { non-consumed sludge in the } \\
\text { MFC was returned to the MBR }\end{array}$ & & & \\
\hline Carbon brush & Stainless steel & Both anode and cathode were & Synthetic wastewater & $1.16 \mathrm{~W} / \mathrm{m}^{3}$ & Tian et al. [77] \\
\hline Anaerobic & Anaerobic & separated by Nafion membrane & & & \\
\hline $180 \mathrm{~mL}$ & $150 \mathrm{~mL}$ & & & & \\
\hline Carbon felt & Carbon felt & MFC was combined with & Synthetic wastewater & $0.06 \mathrm{~W} / \mathrm{m}^{2}$ & Wang et al. [78] \\
\hline Anaerobic & Aerobic & side-stream tubular membrane & & & \\
\hline $2.5 \mathrm{~L}$ & $2.5 \mathrm{~L}$ & $\begin{array}{l}\text { cross-flow filtration system } \\
\text { similar to [74]. }\end{array}$ & & & \\
\hline $\begin{array}{l}\text { Graphite granules with } \\
\text { carbon tube }\end{array}$ & Stainless steel & $\begin{array}{l}\text { Both anode and cathode were } \\
\text { separated by porous spacer in } \\
\text { aeration tank similar to [27]. }\end{array}$ & Synthetic wastewater & $0.15 \mathrm{~W} / \mathrm{m}^{3}$ & Liu et al. [25] \\
\hline Anaerobic & Aerobic & & & & \\
\hline $5.7 \mathrm{~L}$ & $8.2 \mathrm{~L}$ & & & & \\
\hline $\begin{array}{c}\text { Graphite/ conductive } \\
\text { membrane }\end{array}$ & Conductive membrane & $\begin{array}{l}\text { Aeration tank of MBR was } \\
\text { used as cathode chamber }\end{array}$ & Synthetic wastewater & $\begin{array}{l}44.8 \mathrm{~mW} / \mathrm{m}^{2} \\
13.02 \mathrm{~mW} / \mathrm{m}^{2}\end{array}$ & Li et al. [79] \\
\hline Anaerobic & Aerobic & similar to $[72]$ & & & \\
\hline $220 \mathrm{~mL}$ & $1.1 \mathrm{~L}$ & & & & \\
\hline Carbon felt & Stainless steel & Anode and cathode chambers & Synthetic wastewater & $7.18 \mathrm{~mW} / \mathrm{m}^{2}$ & Zhou et al. [80] \\
\hline Anaerobic & Aerobic & were connected through an & & & \\
\hline $0.43 \mathrm{~L}$ & $0.85 \mathrm{~L}$ & $\begin{array}{l}\text { overflow channel without } \\
\text { cation exchange membrane. }\end{array}$ & & & \\
\hline PANi cloth & $\begin{array}{c}\text { Catalyst coated } \\
\text { conductive membrane }\end{array}$ & $\begin{array}{l}\text { Both anode and cathode were } \\
\text { immersed in aeration tank. }\end{array}$ & Synthetic wastewater & $135 \mathrm{~mW} / \mathrm{m}^{2}$ & Yu et al. [81] \\
\hline Aer & & & & & \\
\hline & & & & & \\
\hline
\end{tabular}

*Unit of power density varies due to normalized with chamber volume or electrode area

The first novel bioelectrical MBR was developed by Wang et al. [71]. Wang et al. [71] integrated MBR and MFC in a hybrid assembly using stainless steel mesh as cathodic membrane. Their study obtained a maximum power density of $4.35 \mathrm{~W} / \mathrm{m}^{3}$ and high-quality effluent due to biofilm attached on the membrane. However, the design complexity where stainless steel mesh served as both biocatalyst and filtration function makes it practically impossible. Later, Wang et al. [72] established a more practical MFC-MBR system where aeration tank of MBR was directly used as cathode chamber. This system generated higher power density $\left(6 \mathrm{~W} / \mathrm{m}^{3}\right)$ and suitable for large-scale continuous operation due to its simplicity. Thereafter, Wang et al. [74] tested the performance of side-stream cross-flow filtration with tubular membrane. Unlike submerged membrane, the side-stream tubular membrane has higher permeate flux and easier membrane replacement. 
In order to fully integrate both MFC-MBR system, Su et al. [82] fed activated sludge from MBR to MFC for bioelectricity generation while the non-consumed sludge in MFC was recycled back to MBR to reduce sludge production as illustrated in Figure 13. Excellent COD and ammonia removal (more than $90 \%$ ) was successfully achieved with sludge reduction was $5.1 \%$ higher than that of the conventional MBR. Besides, the operation cycle in the combined system was nearly twice compared to the conventional MBR signified excellent membrane fouling suppression. This novel self-sustained EMBR configuration allows maximum sludge reduction and energy recovery.
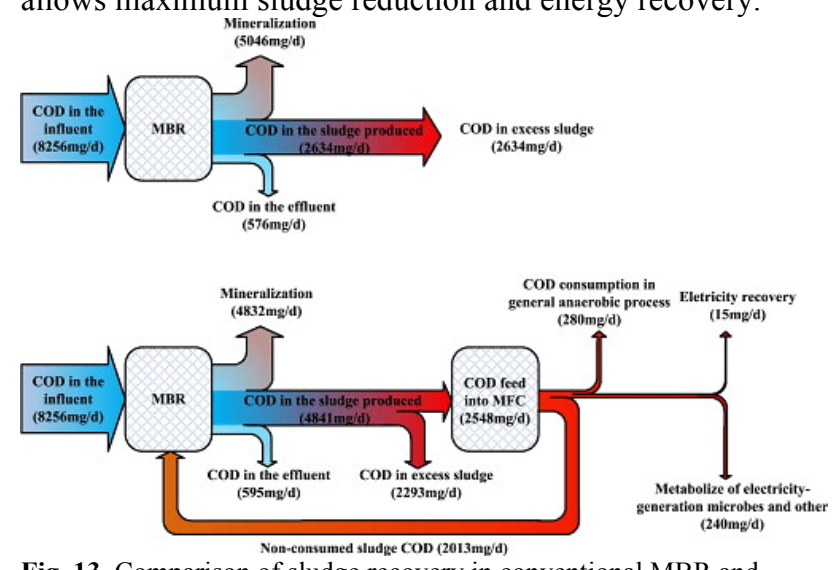

Fig. 13. Comparison of sludge recovery in conventional MBR and self-sustained EMBR [82]

In most of the previous research, IEM was used to separate anodic chamber and cathodic chamber. Nevertheless, the use of IEM increases the overall internal resistance and the overall cost of the system [75]. Recently, a novel overflow-type MFC-MBR was developed by Zhou et al. [80] where the anodic and cathodic chambers were separated by an overflow channel allowing wastewater with protons and substrate overflow directly into the cathode from the anode and restricting oxygen to transfer from the cathode to the anode as shown in Figure 14. This novel MFC-MBR without IEM generates a maximum power density of $7.18 \mathrm{~mW} / \mathrm{m}^{2}$ and excellent COD $(92.6 \%)$, ammonia nitrogen $(96.5 \%)$, and total nitrogen $(73.9 \%)$ removal.

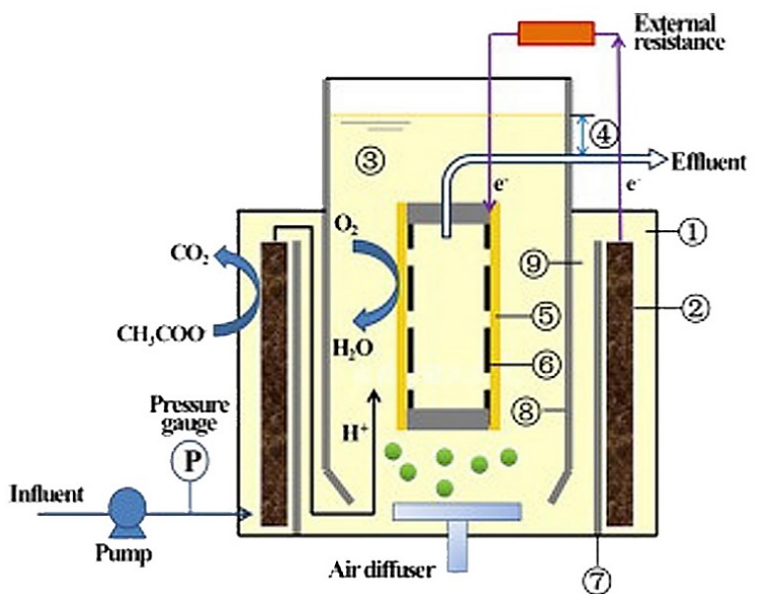

Fig. 14. Schematic diagram of overflow-type EMBR (1) Anodic chamber (2) graphite anode (3) cathodic chamber (4) hydraulic head (5) biofilm (6) stainless steel mesh (7) anodic chamber inner tube (8) cathodic chamber tube (10) overflow channel [80]

Previously, low-cost conductive membranes have proved its ability to outperform the noble metal or filter cloth for EMBR operation. Liu et al. [27] started to employ Fe mesh as anode and PPy modified filter as cathode membrane. The bioelectricity generation was contributed by both corrosions of $\mathrm{Fe}$ mesh and microbial activity on anode. However, the power density was not high due to the combination of anode and cathode chambers in aerobic zone. Subsequently, Li et al. [79] obtained a maximum power density of $44.8 \mathrm{~mW} / \mathrm{m}^{2}$ when using conductive polyester membrane modified with PANi as cathodic membrane and graphite as anode. The research group further replaced the graphite anode with PANi modified membrane but generated lower maximum power density at $13.02 \mathrm{~mW} / \mathrm{m}^{2}$. Their studies concluded that electricity generated was indeed low but it showed significant improvement compared with conventional filter cloth which is insulator in the nature form. This new invention encouraged more studies to be conducted in improving the electricity generation using conductive membrane as electrodes. In more recent development, $\mathrm{Yu}$ et al. [81] used PANi modified membrane as anode and catalyst coated conductive membrane as cathodic membrane. The coating of catalyst made of carbon, cobalt, and $\mathrm{Fe}$ makes the cathodic membrane become catalytic to enhance cathodic oxygen reduction and electricity generation. A maximum power density of $135 \mathrm{~mW} / \mathrm{m}^{2}$ (38.5 times higher than non-catalyst membrane) was obtained due to the enhanced catalytic activity. Cathodic oxygen reduction also generates $\mathrm{H}_{2} \mathrm{O}_{2}$ to oxidize different recalcitrant or macromolecule pollutants into intermediates that can be more readily degraded by bio-electrochemical process.

As compared to external electricity supplied EMBR, self-sustained EMBR offers a great prospect for simultaneous wastewater treatment and energy recovery, suggesting a high economical attractiveness. However, further studies in system design and operating conditions are still in demand to enable high-quality effluent and energy generation.

\section{Conclusion and future prospect}

As evidenced from the presented literature, many studies have been conducted to study the application of electricity in EMBR for membrane fouling suppression and performance enhancement. Most of the studies focus on the development of reactor design configuration and manipulation of electrodes to maximize the benefits of integrated system.

Despite the advantages of MBR over the conventional wastewater treatment, widespread application of MBR is hindered by frequent membrane fouling. EMBR has not only shown significant improvement in membrane fouling suppression but also overall performance including enhanced permeate flux and pollutant removal/degradation. This is attributed to the increased electrorepulsive force between foulants and membrane surface by electric field (electrophoresis) and formation of flocs with coagulants released from sacrificial anodes (electrocoagulation). As a result, the adhesion of negatively-charged foulants on membrane surface would be reduced significantly. Besides, the electrochemical oxidation and reduction are proven to degrade pollutants and provide in-situ membrane cleaning by $\mathrm{H}_{2} \mathrm{O}_{2}$ generation, respectively. Therefore, the hybrid system of MBR and electrokinetic process is specified with synergetic enhancement effect.

Self-sustained EMBR offers numerous advantages over external electricity supplied EMBR by treating wastewater and recovering energy simultaneously. However, there is lack of investigation on the feasible use of self-sustained 
EMBR pilot plant in treating wastewater. Due to a large amount of wastewater produced from both municipal and industry, it is urge to study the scale-up self-sustained EMBR for long-term operation to demonstrate its practicality. Besides, more studies should also focus on economic costs analysis between external electricity MBR and self-sustained EMBR in term of capital cost as well as operating and maintenance (O\&M) cost.

In overall, conductive membranes offer more advantages than noble metal and filter cloth due to their enhanced electroconductivity and lower cost. Nevertheless, conductive membrane requires complicated fabrication process and cannot synthesized by classical phase inversion method. Hence, more studies should focus on the development of efficient conductive membrane fabrication method to enable cost-effective mass production. Besides, additional studies are suggested in optimizing the operating conditions, reactor design, and investigating the impacts of electric field/ electrocoagulation on microbial growth/sludge to render this promising technical solution for wastewater treatment.

\section{Acknowledgement}

The authors wish to gratefully acknowledge the financial support for this work by Geran Gerakan Penyelidik Muda (GGPM-2016-030), Sime Darby Research Grant (KK-2014-016) and sponsorship of K.C. Ho's postgraduate study by Yayasan Sime Darby.

This is an Open Access article distributed under the terms of the Creative Commons Attribution Licence

\section{References}

1. G. Tchobanoglous, F.L. Burton, H.D. Stensel, Wastewater engineering: treatment and reuse. Metcalf \& Eddy, McGraw-Hill Education, USA, (2003).

2. K. Wang, A.A. Abdalla, M.A. Khaleel, N. Hilal, M.K. Khraisheh, Desalination, 401, pp. 190-205 (2016).

3. M.H. Gerardi, The Microbiology of Anaerobic Digesters, Wiley, Canada, (2003).

4. A.L. Ahmad, S. Ismail, S. Bhatia, Desalination, 157, pp. 87-95 (2003).

5. Y. Zhang, L. Yan, X. Qiao, L. Chi, X. Niu, Z. Mei, Z. Zhang, Journal of Environmental Sciences, 20, pp. 558-564 (2008).

6. H. Park, I. Chang, K. Lee, Principles of Membrane Bioreactors for Wastewater Treatment Waste activated sludge, CRC Press, Florida, (2015).

7. S. Judd, C. Judd, The MBR Book: Principles and Aplications of Membrane Bioreactors for Water and Wastewater Treatment. Butterworth Heinemann, UK, (2006).

8. Y.K. Wang, G.P. Sheng, W.W. Li, H.Q. Yu, Bioresource Technology, 122, pp. 17-21 (2012).

9. R. Umaiyakunjaram, P. Shanmugam, Bioresource Technology, 216, pp. 785-792 (2016).

10. Z. Badani, H. Ait-Amar, A. Si-Salah, M. Brik, W. Fuchs, Desalination, 185, pp. 411-417 (2005).

11. M. Matošić, I. Prstec, H.K. Jakopović, I. Mijatović, Desalination, 246, pp. 285-293 (2009).

12. Z. Ahmad, M.B. Ridzuan, Z. Daud, International Conference on Sustainable Development for Water and Waste Water Treatment, Indonesia, (2009).

13. J. Sipma, B. Osuna, N. Collado, H. Monclús, G. Ferrero, J. Comas, I. Rodriguez-Roda, Desalination, 250, pp. 653-659 (2010).

14. W. Guo, H.H. Ngo, J. Li, Bioresource Technology, 122, pp. 27-34 (2012).

15. A. Drews, Journal of Membrane Science, 363, pp. 1-28 (2010).

16. F. Meng, F. Yang, B. Shi, H. Zhang, Separation and Purification Technology, 59, pp. 91-100 (2008).

17. J. Phattaranawik, A.G. Fane, A.C.S. Pasquier, B. Wu, AIChE Journal, 53, pp. 243-248 (2007).

18. H. Wang, Z. Chen, J. Miao, Y. Li, Bioresource Technology, 209, pp. 318-325 (2016).

19. J. Wu, P. Le-Clech, R.M. Stuetz, A.G. Fane, V. Chen, Journal of Membrane Science, 324, pp. 26-32 (2008).

20. M. Zhang, B. qiang Liao, X. Zhou, Y. He, H. Hong, H. Lin, J. Chen, Bioresource Technology, 175, pp. 59-67 (2015).

21. M.R. Bilad, G. Mezohegyi, P. Declerck, I.F.J. Vankelecom, Water Research, 46, pp. 63-72 (2012).

22. J.-P. Chen, C.-Z. Yang, J.-H. Zhou, X.-Y. Wang, Chemical Engineering Journal, 128, pp. 177-180 (2007).

23. V. Wei, J.A. Oleszkiewicz, M. Elektorowicz, Water Science and Technology: A Journal of the International Association on Water Pollution Research, 60, pp. 3159-3163 (2009).

24. B. Sarkar, S. Pal, T.B. Ghosh, S. De, S. DasGupta, Journal of Membrane Science, 311, pp. 112-120 (2008).

25. J. Liu, L. Liu, B. Gao, F. Yang, J. Crittenden, N. Ren, International
Journal of Hydrogen Energy, 39, pp. 17865-17872 (2014).

26. Y. Zhang, L. Liu, F. Yang, Journal of Applied Polymer Science, 133, pp. 43597-43605 (2016).

27. J. Liu, L. Liu, B. Gao, F. Yang, Journal of Membrane Science, 430, pp. 196-202 (2013).

28. L. Liu, J. Liu, G. Bo, F. Yang, J. Crittenden, Y. Chen, Journal of Membrane Science, 429, pp. 252-258 (2013).

29. F. Zhao, L. Liu, F. Yang, N. Ren, Chemical Engineering Journal, 230, pp. 491-498 (2013).

30. N. Li, L. Liu, F. Yang, Desalination, 338, pp. 10-16 (2014).

31. F. Ahmed, B.S. Lalia, V. Kochkodan, N. Hilal, R. Hashaikeh, Desalination, 391, pp. 1-5 (2015).

32. J. Zhang, A. Satti, X. Chen, K. Xiao, J. Sun, X. Yan, P. Liang, X. Zhang, X. Huang, Chemical Engineering Journal, 273, pp. 223-230 (2015).

33. K. Bani-Melhem, M. Elektorowicz, Environmental Science and Technology, 44, pp. 3298-3304 (2010).

34. A.N. Alshawabkeh, Y. Shen, K.Y. Maillacheruvu, Environmental Engineering Science, 21, pp. 321-329 (2004).

35. A. Aouni, C. Fersi, M. Ben Sik Ali, M. Dhahbi, Journal of Hazardous Materials, 168, pp. 868-874 (2009).

36. A. Giwa, I. Ahmed, S.W. Hasan, Journal of Environmental Management, 159, pp. 78-85 (2015).

37. A.W. Mohammad, Y.H. Teow, W.L. Ang, Y.T. Chung, D.L. Oatley-Radcliffe, N. Hilal, State-of-the-Art Reviews in Desalination, 356, pp. 226-254 (2015).

38. W.L. Ang, A.W. Mohammad, Y.H. Teow, A. Benamor, N. Hilal, Separation and Purification Technology, 152, pp. 23-31 (2015).

39. C. García-Gómez, P. Drogui, B. Seyhi, P. Gortáres-Moroyoqui, G. Buelna, L.H. Álvarez, M.I. Estrada-Alvarado, Journal of the Taiwan Institute of Chemical Engineers, 64, pp. 211-219 (2016).

40. Y. Liu, J. Xie, C.N. Ong, C.D. Vecitis, Z. Zhou, Environ. Sci.: Water Res. Technol, 1, pp. 769-778 (2015).

41. J. Huang, Z. Wang, J. Zhang, X. Zhang, J. Ma, Z. Wu, Sci Rep. 5, pp. $9268(2015)$.

42. K. V. Plakas, A.J. Karabelas, Electrochemical advanced oxidation proceses for water treatment-Progress and promises, in: CIMEE, Liban, 2016.

43. Y.H. Lee, F. Li, K.H. Chang, C.C. Hu, T. Ohsaka, Applied Catalysis B: Environmental, 126, pp. 208-214 (2012).

44. J.P. Chen, C.Z. Yang, J.H. Zhou, Chemical Engineering and Technology, 30, pp. 1262-1265 (2007).

45. K. Akamatsu, W. Lu, T. Sugawara, S. ichi Nakao, Water Research, 44, pp. 825-830 (2010).

46. K. Akamatsu, Y. Yoshida, T. Suzaki, Y. Sakai, H. Nagamoto, S.I. Nakao, Separation and Purification Technology, 88, pp. 202-207 (2012).

47. F. Ceuret, E. Oliveira Vilar, E. Bezerra Cavalcanti, Journal of Applied Electrochemistry, 32, pp. 1175-1182 (2002).

48. L. Liu, J. Liu, B. Gao, F. Yang, Separation and Purification Technology, 86, pp. 106-112 (2012).

49. L. Liu, F. Zhao, J. Liu, F. Yang, Journal of Membrane Science, 437, pp. 99-107 (2013). 
50. T. Wang, H. Zhao, H. Wang, B. Liu, C. Li, Chemosphere, 155, pp. 94-99 (2016).

51. A.H. Hawari, F. Du, M. Baune, J. Thöming, Journal of Environmental Sciences (China), 29, pp. 139-145 (2015).

52. K. Bani-Melhem, M. Elektorowicz, J. Oleszkiewicz, Proceedings of the Water Environment Federation, 41-50, pp. 2771-2783 (2009).

53. S. Ibeid, M. Elektorowicz, J.A. Oleszkiewicz, Proceedings, Annual Conference - Canadian Society for Civil Engineering, 1, pp. 634 640 (2010).

54. K. Bani-Melhem, M. Elektorowicz, Journal of Membrane Science, 379, pp. 434-439 (2011)

55. M. Elektorowicz, S.W. Hasan, J.A. Oleszkiewicz, Proceedings of the Water Environment Federation, WEFTEC 51-60. pp. 3605$3611(2011)$

56. S.W. Hasan, M. Elektorowicz, J.A. Oleszkiewicz, Bioresource Technology, 120, pp. 199-205 (2012).

57. V. Wei, M. Elektorowicz, J.A. Oleszkiewicz, Water Science and Technology, 65, pp. 737-742 (2012).

58. L. Liu, J. Liu, B. Gao, F. Yang, S. Chellam, Journal of Membrane Science, 394-395, pp. 202-208 (2012).

59. J. Liu, L. Liu, B. Gao, F. Yang, Separation and Purification Technology, 100, pp. 44-50 (2012).

60. K. Bani-Melhem, E. Smith, Chemical Engineering Journal, 198199, pp. 201-210 (2012)

61. S. Ibeid, M. Elektorowicz, J.A. Oleszkiewicz, Water Research, 47, pp. 903-910 (2013).

62. S.W. Hasan, M. Elektorowicz, J.A. Oleszkiewicz, Chemosphere, 97, pp. 71-77 (2014).

63. M. Hosseinzadeh, G.N. Bidhendi, A. Torabian, N. Mehrdadi, M. Pourabdullah, Bioresource Technology, 192, pp. 177-184 (2015).

64. S. Ibeid, M. Elektorowicz, J.A. Oleszkiewicz, Journal of Membrane Science, 494, pp. 136-142 (2015).

65. A.D. Tafti, S.M. Seyyed Mirzaii, M.R. Andalibi, M. Vossoughi, Separation and Purification Technology, 152, pp. 7-13 (2015).

66. M. Elektorowicz, J. Oleszkiewicz, K. Bani-Melhem, US Patent
2010/0051542 (2010).

67. DOE, Code of Scheduled Waste, (2013).

68. H. Kanematsu, D.M. Barry, Biofilm and Materials Science, Springer International Publishing, Switzerland, (2015).

69. B. Min, I. Angelidaki, Journal of Power Sources, 180, pp. 641-647 (2008).

70. S. Venkata Mohan, G. Mohanakrishna, B.P. Reddy, R. Saravanan, P.N. Sarma, Biochemical Engineering Journal, 39, pp. 121-130 (2008).

71. Y.K. Wang, G.P. Sheng, W.W. Li, Y.X. Huang, Y.Y. Yu, R.J. Zeng, H.Q. Yu, Environmental Science and Technology, 45, pp. 92569261 (2011)

72. Y.P. Wang, X.W. Liu, W.W. Li, F. Li, Y.K. Wang, G.P. Sheng, R.J. Zeng, H.Q. Yu, Applied Energy, 98, pp. 230-235 (2012).

73. J. Song, L. Liu, F. Yang, N. Ren, J. Crittenden, Bioresource Technology, 147, pp. 409-415 (2013).

74. J. Wang, Y. Zheng, H. Jia, H. Zhang, Bioresource Technology, 149, pp. 163-168 (2013).

75. Y.K. Wang, W.W. Li, G.P. Sheng, B.J. Shi, H.Q. Yu, Water Research, 47, pp. 5794-5800 (2013).

76. X. Su, Y. Tian, Z. Sun, Y. Lu, Z. Li, Biosensors and Bioelectronics, 49, pp. 92-98 (2013).

77. Y. Tian, C. Ji, K. Wang, P. Le-Clech, Journal of Membrane Science, 450, pp. 242-248 (2014).

78. J. Wang, Y. Zheng, H. Jia, H. Zhang, Bioresource Technology, 170, pp. 483-490 (2014).

79. N. Li, L. Liu, F. Yang, Separation and Purification Technology, 132, pp. 213-217 (2014).

80. G. Zhou, Y. Zhou, G. Zhou, L. Lu, X. Wan, H. Shi, Bioresource Technology, 196, pp. 648-655 (2015).

81. T. Yu, L. Liu, Q. Yang, J. Song, F. Yang, Rsc Advances, 5, pp. 48946-48953 (2015).

82. X. Su, Y. Tian, Z. Sun, Y. Lu, Z. Li, Biosensors and Bioelectronics, 49, pp. 92-98 (2013) 